\title{
CURRENT PROBLEMS OF CORRUPTION-ADMINISTRATIVE OFFENSES
}

Corruption remains one of the largest political and socio-economic problems in Ukraine, which hinders the development of state and civil society, deepens social crisis phenomena and in general undermines the image of Ukraine on the world stage. The development and implementation of anticorruption measures, in particular legal responsibility, in practice require the strict observance of the procedures for their application in order to prevent violations of the rights of those concerned. It is a question of ensuring a balance between the inevitability of the punishment of a person who committed an offense related to corruption and its rights and freedoms guaranteed by current legislation. Achievement of the formulated goal is carried out with the help of complex and consistent application of the corresponding scientific tool presented by such methods of scientific knowledge as logic-semantic, systemic, structural-logical, methods of analysis and synthesis, etc.

The purpose of the paper is to study the problems of legal regulation of proceedings in prosecution for violations related to corruption and to formulate proposals for their solution. The stated goal is achieved through the complex and consistent application of appropriate scientific tools, presented by such methods of scientific cognition as logical-semantic, systemic, structural-logical, methods of analysis and synthesis, etc.

Results. The article analyzes the issue of administrative liability for corruption offenses. The gaps in the legal regulation of liability for offenses related to corruption are revealed, ways of solving the above problems are offered. The attention is focused on the necessity of observing the guarantees of a fair court in bringing the person to administrative liability for offenses related to corruption.

Conclusions. Since the norms of Code of Ukraine on administrative offenses do not allow to fully ensure the right to a fair trial, the urgent need is to develop and adopt a law on amendments to the Code of Criminal Procedure or its new edition, which would take into account the practice of the European Court of Human Rights, including in cases of offenses related to with corruption.

Key words: administrative liability, offenses related to corruption, human rights guarantees, right to a fair trial. 


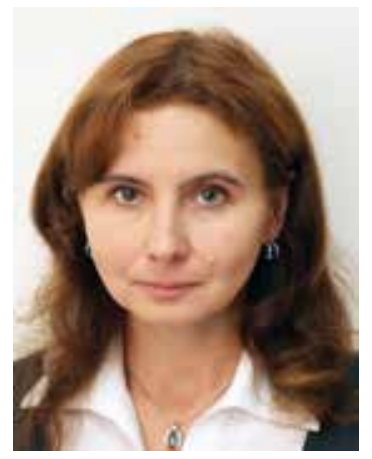

Boiko Iryna, Associate Professor of the Department of Administrative Law of Yaroslav Mudryi National Law University,

PhD in Law orcid.org/0000-0003-3878-5985 ir_boiko@ukr.net

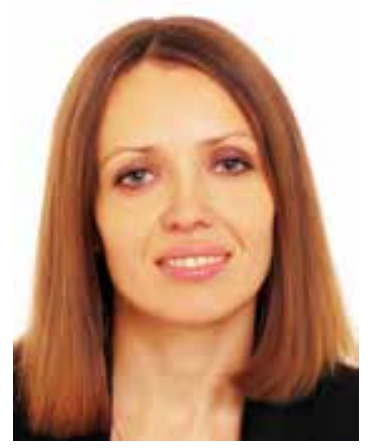

Soloviova Olha, Associate Professor of the Department of Administrative Law of Yaroslav Mudryi National Law University,

PhD in Law

orcid.org/0000-0003-3801-9113 o.m.soloviova@gmail.com

\section{Introduction}

For a long time, corruption remains one of the largest political and socio-economic problems in Ukraine, which affects the development of state and civil society, increases social crisis phenomena and in general misrepresents the image of Ukraine on the world stage. In the Corruption Perceptions Index (CPI), which is established by Transparency International in 2018, our country ranked 120 in the list of 180 countries in the world. Although the position of Ukraine in the rating is improving year by year, such state of affairs is still far from satisfactory. The development and implementation of anticorruption measures, in particular legal liability, in practice require the precise compliance with the procedures for their application in order to prevent rights violations of those concerned. It is a matter of ensuring balance between the inevitable punishment of a person who committed an offense related to corruption and his rights and freedoms guaranteed by current legislation.

The issues of preventing and combating corruption are reflected in the work of many researchers, and not only representativesoflegalscience(N.P.Bortnik,M.I.Khavronyuk, D.O. Kalmykov, O.H. Kalman, M.O. Melnik). At the same time, the analysis of rights accordance of individuals brought to administrative liability for corruption offenses did not reach the general public. Taking into account the abovementioned, the article will investigate the problems of legal regulation of proceedings in prosecution for such violations and their possible solutions.

The significance of administrative liability for corruptionrelated offenses is that such misconduct is the most widespread form of delinquency, and thus constitute a complex negative social phenomenon. Due to its application, the prevention of dangerous offenses is implemented, including crimes related to corruption.

Since the society in whole has a great interest in overcoming corruption, the development and application of a mechanism for bringing to administrative liability becomes important, excluding any doubts as to the legality and fairness of the corresponding penalty. It is significant to have an established system of human rights guarantees, when a person is brought to administrative liability for corruptionrelated offenses. What guarantees of human rights must be ensured when brought to administrative liability? 


\section{Legitimacy as the principle of bringing a person to administrative liability for offenses related to corruption}

First of all, it is worth paying attention to the legitimacy of imposing administrative penalties. In accordance with part 3 of art. 7 Code of Ukraine on Administrative Offenses (hereinafter - CUAO), the use of administrative measures authorized by the officials is carried out within the limits of their competence, in strict conformity with the law (Verkhovna Rada of the Ukrainian SSR, 1984).

Corruption offenses include penalties such as fines, confiscation (income, rewards, gifts, money) and deprivation of the right to occupy certain positions or engage in certain activities. The fine is the basic penalty for any offense related to corruption. Confiscation is used as an extra charge that has to be imposed, since the sanction of articles is formulated in such a way that confiscation (as an additional charge) is mandatory. Regarding the third type of penalty, according to part 6 of art. 30 CUAO deprivation of the right to occupy certain positions or engage in certain activities is appointed by the court for one year, when it is specifically provided for in the sanction of the article (sanctions of part of the article) of the Special Part of the CUAO, when, taking into account the nature of the administrative offense committed for office, the person who committed an administrative offense, and other circumstances of the case, the court recognizes the impossibility of preserving for her the right to occupy certain positions or engage in certain activities. Thus, the court has broad powers to enforce judgment even when imposing a penalty that is not in the sanction of the article.

In our opinion, such a position of the legislator, set forth in part 5 of art. 30 CUAO, contradicts the general principles of legal liability, in particular, imposing penalties within the limits established by the sanction of the article. As judicial practice shows, courts often apply the provisions of part 5 of art. 30 CUAO, but do not indicate which circumstances indicate that a person can not continue to hold positions (for example, in court decisions such an argument is encountered that the court finds it impossible to preserve the right of a person to occupy certain positions or engage in certain activities (Mukachevo City District Court of Zakarpattia region, 2016) or an offense is directly related to his being in office (Pechersk District Court of Kyiv, 2016). We see this as a gross violation as the judge, using the court's discretion and imposing a penalty that is not in the sanctions of the article, should argue and give concrete reasons why the person can not continue to hold positions in the future. However, this is not the only problem while imposing penalties for corruption offenses. Indeed, the sanctions of part 3 of art. 172-4, part 2 of art. 172-5, part 3 of art. 172-6, part 2 of art. 172-9-1 contain a penalty in the form of a certain amount of fine with the confiscation of received income or rewards (gifts, donations, money) and with the deprivation of the right to occupy certain positions or engage in certain activities for a period of one year. That is, the legislator, setting an increased responsibility for qualified offenses (these are cases where the misconduct is committed by individuals who have already been brought to administrative responsibility in the previous year under the previous parts of the relevant articles), imposes on individuals three types of penalties. This situation does not coincide with the part 2 of art. 25 CUAO, stating that one person is subject to one basic or a basic and an additional administrative charge for one administrative offence. According to 
Part 1 of this article, confiscation of items may be applied to as both the basic and additional administrative charge; deprivation of the right to occupy certain positions or engage in certain activities - only as additional; other administrative charges - only as the basic ones. That is, in cases of committing offenses stipulated by the said articles, one basic and two additional penalties should be imposed on the person. Consequently, in practice there are cases where one person should be subject to three types of charges for one offense. The legal literature has repeatedly emphasized the need for a clear demarcation of the basic and additional penalties (Khoroshchak, 2003). Thus, it is noted that the application of the legally fixed basic administrative penalties constitutes the punishment of the offender as the main purpose, and the simultaneous application of additional penalties provides, along with the punishment of the offender, the elimination of the conditions for the further offenses or is compensatory in nature.

A clear delineation of the basic and additional penalties on the indicated features enables to adhere to the principle of guilt and punishment being applied. Otherwise, one can conclude that, when applying the basic and additional sanctions, which in turn serve as separate types of administrative penalties and are administrative-legal coercion, two penalties are imposed on a person, which, in turn, violates the requirements of art. 61 of the Constitution of Ukraine (Verkhovna Rada of Ukraine, 1996).

Regarding judicial practice, the register of judgments contains few resolutions on the specified articles in which a person is charged with administrative penalty in the form of a fine with confiscation of income or remuneration and with the deprivation of the right to occupy certain positions or engage in certain activities for one year (i. e. all three charging at the same time) (Mykolaiv district court of Odessa region, 2018) or only a penalty payment (ignoring other penalties specified in the sanction) (Velikonoselkovsky District Court of Donetsk region, 2018). We see the existing situation as contradicting the general principles of ensuring human rights, guaranteed by the Constitution of Ukraine and international acts. The principle of legality is also connected with the statute of limitations for imposing administrative penalties, stipulated in part 3 of art. $38 \mathrm{CUAO}$. For their correct calculation, it is necessary to establish the time when the offense was committed or detected.

It should be noted that neither CUAO nor the Law of Ukraine "On Prevention of Corruption" specify what is to be considered as the moment of detection of an offense, including corruption-related ones. An analysis of judicial practice allows us to conclude that there are three approaches to establishing such a moment: either this is the date of recording an administrative offense; or the day when the authorized body receives information which implies the signs of an offense related to corruption in the person's deed; or it is the day when the authorized body sets down in writing explanations of a person who is a subject of a further minutes record about committing of an offense connected with corruption.

In legal literature there is no unambiguous approach to the definition of the legal nature of the records on administrative violations. Thus, some authors consider the minutes as the basis for the consideration of an administrative case (Ignatenko, 2015); others as a source of evidence (Lukyanets, 2010). According to L.V. Koval, the minutes is the beginning of proceedings in administrative offenses (Koval, 1994). M.I. Horodyskyi 
and V.A. Humeniuk consider it as a procedural document, which marks the end of the stage of administrative disputes, which is, most likely, the indictment (Horodyskyi, 1998). In any case, the minutes is an official document, which records the fact of committing an administrative misconduct. Consequently, all suggested definitions are allowed, depending on the selection of particular stages of the proceedings. To date, CUAO clearly establishes that the minutes has to be recorded not later than twenty-four hours from the moment of detection the person who committed the offense, in duplicate, one of which is submitted to the person who is being brought to administrative responsibility (part 2 of art. 254). It is implied that from the moment of detection and up to the moment of drawing up the minutes it should take no more than 24 hours. And if the moment of receiving information about an administrative offense related to corruption will differ from the moment of record, it should also be clearly stated in other official documents of the relevant official or official of the specially authorized body.

Supposing the first two approaches have the right to exist, although in our opinion, in the meantime, one must base on the moment of recording the minutes on committing an offense connected with corruption (since this is precisely this moment clearly stated in the rules of CUAO), the third is fairly criticized (Zahorska, 2017) in respect of the constitutional norm that a person is not accountable for refusing to testify or explain conduct of his or her family members or close relatives, the circle of which is determined by law (art. 63 of the Constitution of Ukraine).

Since the fact of committing (detecting) an offense is recorded, in most cases it is precisely the clear and objective statement of all the circumstances of the case record, that defines whether the person will be brought to administrative liability. CUAO does not contain provisions for a situation in which the minutes does not contain certain information or certain errors are made. In his letter, the High Specialized Court of Ukraine for Civil and Criminal Cases (hereinafter - the HSCU) drew the attention of judges to the practical aspects of bringing to administrative liability for certain offenses related to corruption, and noted that in the case when the record was performed by a not authorized person or without observance of the requirements established by art. 256 CUAO, the judge is obliged by his decision to return the record to the appropriate law-enforcement body (specially authorized anti-corruption party, who has made the record) for proper registration (High Specialized Court of Ukraine for Civil and Criminal Cases, 2017). At the same time, the resolution on sending a protocol on an administrative offense related to corruption, for proper registration (elimination of deficiencies) is not subject to appeal. In our opinion, this position of the HSCU does not comply with the provisions of the CUAO, since the law has been violated as an element of the rule of law.

\section{Guarantees of a fair court in bringing a person to administrative liability for corruption offenses}

When bringing a person to administrative liability, the guarantees of a fair court as a right established in art. 6 of the Convention for the Protection of Human Rights and Fundamental Freedoms (hereinafter - the Convention) (Council of Europe, Verkhovna Rada of Ukraine, 1998) have to be preserved. The essence of the right to a fair trial is to combine the two categories - fairness and justice. Considering cases of administrative offenses, the court also carries out justice. The scope of the outlined 
law is defined in paragraph 1 of art. 6 of the Convention: "Everyone has the right to a fair and public hearing of his case within a reasonable time by an independent and impartial judgment established by law which resolves a dispute over his rights and obligations of a civil nature, or establishes the validity of any criminal charge against him". The analysis of this provision makes it possible to find out the range of objects, judicial protection which should take place with the observance of the requirements of a fair trial. Such objects are the rights and duties of a civil character, as well as human rights in the criminal prosecution.

The European Court of Human Rights extends its own "autonomous" vision of the concept of "criminal prosecution" including certain administrative offenses to criminal ones. This approach necessitates the extension of the guarantees provided for in art. 6 of the Convention, to administrative offenses proceedings. Since, in accordance with the Law of Ukraine "On the Enforcement of Judgments and the Practice of the European Court of Human Rights" (Verkhovna Rada of Ukraine, 2006), courts apply the Convention and the case-law of the Court as a source of law, the ECHR's position on understanding the right to a fair trial must be taken into account by courts when bringing a person to administrative responsibility.

It should be noted that the right to a fair trial is insured by art. 6 of the Convention, containing guarantees, which can be grouped as follows: 1) those which favor the possibility of a judicial hearing of a case, in particular, the formation of a court on the basis of law, the independence and impartiality of the court; 2) those that contribute to the effective judicial protection of the individual - the fairness of the trial; publicity of cases; a reasonable time limit for hearing cases; the presumption of innocence of a person held to administrative liability; the right to protection; possibility to appeal against court decisions.

Guarantees of fair trial are of particular relevance in today's context, when, according to the Chairman of the Council of Judges, 22 courts are not operating in Ukraine in August 2018 (strana.ua/news). The question naturally arises as to how, in such territories, where there are no judges empowered to administer justice, to ensure the principle of accessibility of justice, the right of a person, in particular, to judicial protection. Particular procedural laws contain rules governing the transfer of relevant categories of cases to another court, if there are grounds for doing so. The Code of Administrative Offenses does not give any reason or even the possibility of solving problems of subordinations ${ }^{1}$.

Analyzing the provisions of art. 276 of the Code of Administrative Offenses, it can be noted that, as a general rule, the case should be considered at the place of the offense. According to the Code of Administrative Offenses, there are no legal grounds for changing the place of administrative offense case consideration (except when the rules stipulate alternative jurisdiction and the person has made a request for case consideration at the place of residence or registration of the vehicle). The competent court in cases of administrative

${ }^{1}$ Since the Code of Administrative Offenses of the bodies authorized to consider cases of administrative offenses refers to both judicial and other public authorities, local self-government bodies, the characteristic term for this type of proceedings is "subordination". However, if these are only court cases, the term "jurisdiction", which is not used in the Administrative Code, may apply to them. 
offenses related to corruption will be the court, which has the right to consider cases of offenses within its jurisdiction, that is, subject and territorial jurisdiction, since such rules are provided by the provisions of the CUAO for election of a body to consider cases of administrative offenses. However, if we analyze the practice of courts in which judges cannot administer justice for objective reasons (for example, the expiry of a 5-year term of office or reaching the age of 65), it should be noted that judicial authorities have ruled in the proceedings on administrative offenses concerning referral of cases for trial to the territorial nearest court of first instance (resolution of the Court of Appeal of Dnipropetrovsk region of June 21, 2016 in Case № 33/774/346/16 (Court of Appeal of Dnipropetrovsk region, 2016a), resolution of the Court of Appeal Cherkasy region of June 13, 2016 in case № 710/649/16-p (Court of Appeal Cherkasy region, 2016), resolution of the Court of Appeal of Kyiv region of October 18, 2017 in case № 374/161/17 (Court of Appeal of Kyiv region, 2017)). Thus, the decision of the Court of Appeal of Cherkasy region states that "all judges of the Shpola District Court of Cherkasy region today have procedural obstacles to the administration of justice. Despite the fact that the solution of this issue is not sufficiently settled by the current Code of Administrative Offenses, in particular, art. 257, 276 of CUAO, its final solution is possible by applying the provisions of part 1 of art. 33 and item 2 of part 1 of art. 34 of the Criminal Procedure Code of Ukraine, according to which the aforementioned administrative offense case may and must be referred to another local court, since it is not possible to form a court composition in the Shpola district court". In another case, the Court of Appeal of Dnipropetrovsk region, considering the complaint of the prosecutor against the decision of the Petrykivka District Court to send materials on an administrative offense to a competent court, noted that the appeal of the prosecutor is well-founded, which is explained by the necessity of ensuring the consideration of the case in compliance with the art. 6 of the Convention for the Protection of Human Rights and Fundamental Freedoms, since it is currently impossible to create a new court in the Magdalinivka District Court of Dnipropetrovsk, as three judges of that court have expired office service and one judge has reached the age of 65 (Court of Appeal of Dnipropetrovsk region, 2016b).

In our view, the position set out in the court's rulings on the change of jurisdiction in administrative cases is disputable. In addition, these resolutions were not adopted due to the need to comply with art. 6 of the Convention, but contrary to the right to a fair trial of a person held to administrative liability. It seems unclear how the need to comply with art. 6 of the Convention relates to a violation of the prosecution proceedings and to the right to a fair trial of a person brought to administrative responsibility. Apparently, the accessibility to justice does not manifest itself in the conviction of a person in any case, even with a violation of law. Ignoring the rules of subordination (jurisdiction), especially in cases involving enforcement of coercive measures, is a material violation of that person's rights and is in no way consistent with the ECHR's international practice. There is therefore every reason to challenge such court decisions, including appealing to the ECHR on such basis.

\section{Attorney's involvement in administrative cases related to corruption}

Another problem that requires legislative regulation or the development of a single court practice is the requirement of the Administrative Code for mandatory involvement of the prosecutor in corruption cases (art. 250 of the CUAO). However, the prosecutor 
does not have the right to challenge the decision on these cases, since according to part 5 of art. 7 of the Code of Administrative Offenses, the prosecutor supervises the observance of laws in the application of measures of influence for administrative offenses by exercising the powers to supervise the observance of laws in the application of compulsory measures related to the restriction of personal freedom of citizens. Charges for corruption offenses do not limit the personal liberty of citizens, and thus the involvement of the prosecutor in such cases is purely formal. Moreover, the prosecutor today is deprived even of the opportunity to draw up reports on such cases. Taking part in these cases, the prosecutor has the right: to get information of the case files; to check the lawfulness of the actions of bodies (officials) during the proceedings; to participate in the hearing of the case; to petition; to give conclusions on issues that arise during the hearing of the case; to check the correctness of influence measures and their application for administrative offenses by the appropriate authorities (officials), as well as to take other actions provided by law. It is still not clear how he can verify the correctness of the impact measures without the right to appeal. Court of Appeal jurisprudence indicates that individual courts accept appeals by prosecutors, despite the fact that such a possibility is not provided for by current legislation. In such situations, the courts should be guided solely by the current legislation of Ukraine and not accept such appeals for consideration, and in turn, the legislator should decide for himself whether surveillance of the prosecutor's office in cases of corruption offenses is necessary and amend accordingly to the law.

\section{Conclusions}

Legality as an element of the rule of law requires that a representative of the authorities, when conducting proceedings in administrative offenses, acts on the basis, in the manner and within the powers provided for by the Constitution and laws of Ukraine including imposition of the penalties, which are enshrined in the relevant article of the Special part of the Code of Ukraine on Administrative Offenses. The standpoint of the legislator towards judgment on the deprivation of the right to hold specific posts or engage in certain activities for the term from six months to one year regardless of whether it is provided in the penal part of the article (penal part of the article's paragraph) of the special part of the Code of Ukraine on Administrative Offenses contradicts the general fundamentals of legal liability, in particular, imposition of the penalties within the limits prescribed by the penal part of the article. Furthermore, the CUAO provides an option to impose penalties in the form of fine with forfeiture of proceeds or rewards and to deprive of the right to hold specific posts or engage in certain activities which is not in line with part 2 of art. 25 of the Code of Ukraine on Administrative Offenses according to which a person shall subject to the basic or basic and additional penalty for one administrative offence.

Norms of the Code of Ukraine on Administrative Offenses do not allow ensuring the right to a fair trial fully of a person who is held to administrative liability for corruption-related offenses fully. Thus, it seems expedient to develop and adopt the law on amendments to the Code of Ukraine on Administrative Offenses and its new revised version which would take into account the European Court of Human Rights practice, including in the cases on corruption-related offences.

Recommendation Rec(2004)5 of the Committee of Ministers on the verification of the compatibility of draft laws, existing laws and administrative practice with 
the standards laid down in the European Convention on Human Rights dated May 12, 2004, which provides the need to test the laws and administrative practice after adoption of a new decision by the European Court of Justice against another member state of the Council of Europe, encourages to the actions.

The lack of a legislative interpretation of the term "individual freedom" neutralizes the idea of prosecution's supervision in corruption-related cases as it deprives the prosecutor of the opportunity to appeal against the judgment: the penalties for such offenses don't restrict the individual freedom of a person. According to art. 5 of the Convention, exclusively administrative arrest can be considered as a measure abridging the individual freedom.

\section{Bibliography:}

1. Кодекс України про адміністративні правопорушення : Закон України від 7 грудня 1984 р. № 8073-Х / Верховна Рада Української РСР. Відомості Верховної Ради Української РСР. 1984. Додаток до № 51. Ст. 1122.

2. Постанова Мукачівського міськрайонного суду Закарпатської області від 9 серпня 2016 р. у справі № 303/4478/16-п / Мукачівський міськрайонний суд Закарпатської області. URL: http://www.reyestr.court.gov.ua/Review/59580742.

3. Постанова Печерського районного суду міста Києва від 18 травня 2016 р. у справі № 757/16965/16-п / Печерський районний суд міста Києва. URL: http:// www.reyestr.court.gov.ua/Review/62087756.

4. Хорощак Н.В. Адміністративні стягнення та ї застосування : автореф. дис. ... канд. юрид. наук : 12.00 .07 «Теорія управління; адміністративне право і процес; фінансове право». Київ, 2003. 15 с.

5. Конституція України : Закон України від 28 червня 1996 р. № 254/96-ВР / Верховна Рада України. Відомості Верховної Ради України. 1996. № 30. Ст. 141.

6. Постанова Миколаївського районного суду Одеської області від 23 серпня 2018 р. у справі № 508/760/18 / Миколаївський районний суд Одеської області. URL: http:// reyestr.court.gov.ua/Review/76433216\#.

7. Постанова Великоновосілківського районного суду Донецької області від 17 серпня 2018 р. у справі № 220/1486/18 / Великоновосілківський районний суд Донецької області. URL: http://reyestr.court.gov.ua/Review/75927179/.

8. Ігнатенко О.П. Удосконалення механізмів притягнення окремих категорій винних осіб до адміністративної відповідальності у сфері благоустрою населених пунктів. Інвестииіï: практика та досвід. 2015. № 1. C. 126-129. URL: http://www.investplan.com.ua/ pdf/1_2015/28.pdf.

9. Лук'янець Д.М. Розвиток інституту адміністративної відповідальності: концептуальні засади та проблеми правореалізації : дис. ... докт. юрид. наук. Київ, 2010. 405 с.

10. Коваль Л.В. Адміністративне право України : курс лекцій. Київ : Основа, 1994. 154 с.

11. Городиський М.I. Адміністративна відповідальність в Україні : навчальний посібник. Харків : Університет внутрішніх справ, 1998. 78 с.

12. Загорська О.I. Темпоральні особливості притягнення до адміністративної відповідальності за правопорушення, пов'язані 3 корупцією. Науковий часопис Національної академії прокуратури України. 2017. № 2(14). C. 68-75. URL: http:// www.chasopysnapu.gp.gov.ua/chasopys/ua/pdf/2-2017/zagorska.pdf.

13. Щодо притягнення до адміністративної відповідальності за окремі правопорушення, пов'язані 3 корупцією : інформаційний лист Вищого спеціалізованого суду України 3 
розгляду цивільних і кримінальних справ від 22 травня 2017 р. № 223-943/0/4-17 / Вищий спеціалізований суд України 3 розгляду цивільних і кримінальних справ. URL: https://zib.com.ua/files/Golovam_apeliacijnih_sudiv_vid_2205_2017.pdf.

14. Конвенція про захист прав людини і основоположних свобод : міжнародний документ Ради Свропи від 4 листопада 1950 р. (ратифікований Законом України від 17 липня 1997 р. № 475/97-ВР) / Рада Європи, Верховна Рада України. Офіиійний вісник Украӥни. 1998. № 13. C. 270.

15. Про виконання рішень та застосування практики Європейського суду 3 прав людини : Закон України від 23 лютого 2006 р. № 3477-IV / Верховна Рада України. Відомості Верховної Ради України. 2006. № 30. Ст. 260.

16. Из-за отсутствия судей в Украине не работают 22 суда. Страна.иа. 2018. 13 августа. URL: https://strana.ua/news/155866-v-ukraine-ne-rabotaet-dva-desjatka-sudov-iz-za-otsutstvijasudej.html.

17. Постанова Апеляційного суду Дніпропетровської області від 21 червня 2016 р. у справі № 33/774/346/16 / Апеляційний суд Дніпропетровської області. URL: http://www.reyestr.court.gov.ua/Review/58480422.

18. Постанова Апеляційного суду Черкаської області від 13 червня 2016 р. у справі № 710/649/16-п / Апеляційний суд Черкаської області. URL: http://www.reyestr.court.gov.ua/ Review/58279344.

19. Постанова Апеляційного суду Київської області від 18 жовтня 2017 р. у справі № 374/161/17 / Апеляційний суд Київської області. URL: http:/www.reyestr.court.gov.ua/ Review/69597068.

20. Постанова Апеляційного суду Дніпропетровської області від 5 серпня 2016 р. у справі № 179/301/16-п / Апеляційний суд Дніпропетровської області. URL: http://reyestr.court.gov.ua/Review/59527762.

\section{References:}

1. Verkhovna Rada of the Ukrainian SSR (1984). Kodeks Ukrainy pro administratyvni pravoporushennia: Zakon Ukrainy vid 7 hrudnia 1984 r. № 8073-X [Code of Administrative Offenses: Law of Ukraine of December 7, 1984 № 8073-X]. Vidomosti Verkhovnoi Rady Ukrainskoi RSR, appendix to no. 51, art. 1122 [in Ukrainian].

2. Mukachevo City District Court of Zakarpattia region (2016). Postanova Mukachivskoho miskraionnoho sudu Zakarpatskoi oblasti vid 9 serpnia 2016 r. u spravi № 303/4478/16-ח [Resolution of the Mukachevo City District Court of Transcarpathian Region of August 9, 2016 in case №303/4478/16-ח].Retrieved from:http://www.reyestr.court.gov.ua/Review/59580742 [in Ukrainian].

3. Pechersk District Court of Kyiv (2016). Postanova Pecherskoho raionnoho sudu mista Kyieva vid 18 travnia 2016 r. u spravi № 757/16965/16-ח [Resolution of the Pechersk District Court of Kyiv of May 18, 2016 in case № 757/16965/16-ח]. Retrieved from: http://www.reyestr. court.gov.ua/Review/62087756 [in Ukrainian].

4. Khoroshchak, N.V. (2003). Administratyvni stiahnennia ta yikh zastosuvannia [Administrative penalties and their application] (Extended abstract of candidate's thesis). Kyiv [in Ukrainian].

5. Verkhovna Rada of Ukraine (1996). Konstytutsiia Ukrainy: Zakon Ukrainy vid 28 chervnia 1996 r. № 254/96-BP [Constitution of Ukraine: Law of Ukraine of June 28, 1996 № 254/96-BP]. Vidomosti Verkhovnoi Rady Ukrainy, no. 30, art. 14 [in Ukrainian].

6. Mykolaiv District Court of Odessa region (2018). Postanova Mykolaivskoho raionnoho sudu Odeskoi oblasti vid 23 serpnia 2018 r. u spravi № 508/760/18 [Resolution of the Mykolaiv 
District Court of Odessa region of August 23, 2018 in case № 508/760/18]. Retrieved from: http:// reyestr.court.gov.ua/Review/76433216\# [in Ukrainian].

7. Velikonoselkovsky District Court of Donetsk region (2018). Postanova Velykonovosilkivskoho raionnoho sudu Donetskoi oblasti vid 17 serpnia 2018 r. u spravi № 220/1486/18 [Resolution of the Velikonoselkovsky District Court of Donetsk region of August 17, 2018 in case № 220/1486/18]. Retrieved from: http://reyestr.court.gov.ua/ Review/75927179/ [in Ukrainian].

8. Ihnatenko, O.P. (2015). Udoskonalennia mekhanizmiv prytiahnennia okremykh katehorii vynnykh osib do administratyvnoi vidpovidalnosti u sferi blahoustroiu naselenykh punktiv [Improvement of mechanisms for bringing certain categories of perpetrators to administrative responsibility in the sphere of settlements improvement]. Investytsii: praktyka ta dosvid, no. 1, pp. 126-129. Retrieved from: http://www.investplan.com.ua/pdf/1_2015/28.pdf [in Ukrainian].

9. Lukianets, D.M. (2010). Rozvytok instytutu administratyvnoi vidpovidalnosti: kontseptualni zasady ta problemy pravorealizatsii [Development of the institute of administrative responsibility: conceptual foundations and problems of right implementation] (Doctor's thesis). Kyiv [in Ukrainian].

10. Koval, L.V. (1994). Administratyvne pravo Ukrainy: kurs lektsii [Administrative law of Ukraine: course of lectures]. Kyiv: Osnova [in Ukrainian].

11. Horodyskyi, M.I. (1998). Administratyvna vidpovidalnist v Ukraini: navchalnyi posibnyk [Administrative responsibility in Ukraine: a textbook]. Kharkiv: Universytet vnutrishnikh sprav [in Ukrainian].

12. Zahorska, O.I. (2017). Temporalni osoblyvosti prytiahnennia do administratyvnoi vidpovidalnosti za pravoporushennia, poviazani z koruptsiieiu [Temporal features of administrative proceedings for corruption offenses]. Naukovyi chasopys Natsionalnoi akademii prokuratury Ukrainy, no. 2(14), pp. 68-75. Retrieved from: http://www.chasopysnapu.gp.gov.ua/chasopys/ua/ pdf/2-2017/zagorska.pdf [in Ukrainian].

13. High Specialized Court of Ukraine for Civil and Criminal Cases (2017). Shchodo prytiahnennia do administratyvnoi vidpovidalnosti za okremi pravoporushennia, poviazani z koruptsiieiu: informatsiinyi lyst Vyshchoho spetsializovanoho sudu Ukrainy z rozghliadu tsyvilnykh i kryminalnykh sprav vid 22 travnia 2017 r. № 223-943/0/4-17 [On administrative liability for certain corruption-related offenses: information sheet of the High Specialized Court of Ukraine for Civil and Criminal Cases of May 22, 2017 № 223-943/0/4-17]. Retrieved from: https://zib.com.ua/files/Golovam_apeliacijnih_sudiv_vid_2205_2017.pdf [in Ukrainian].

14. Council of Europe, Verkhovna Rada of Ukraine (1998). Konventsiia pro zakhyst prav liudyny i osnovopolozhnykh svobod: mizhnarodnyi dokument Rady Yevropy vid 4 lystopada 1950 r. (ratyfikovanyi Zakonom Ukrainy vid 17 lypnia 1997 r. № 475/97-BP) [Convention for the Protection of Human Rights and Fundamental Freedoms: International Council of Europe Document of 4 November 1950 (ratified by Law № 475/97-BP of 17 July 1997)]. Ofitsiinyi visnyk Ukrainy, no. 13, pp. 270 [in Ukrainian].

15. Verkhovna Rada of Ukraine (2006). Pro vykonannia rishen ta zastosuvannia praktyky Yevropeiskoho sudu z prav liudyny: Zakon Ukrainy vid 23 liutoho 2006 r. № 3477-IV [On the enforcement of judgments and the practice of the European Court of Human Rights: Law of Ukraine of February 23, 2006 № 3477-IV]. Vidomosti Verkhovnoi Rady Ukrainy, no. 30, art. 260 [in Ukrainian].

16. Strana.ua (2018). Iz-za otsutstviia sudei v Ukraine ne rabotaiut 22 suda [Due to the lack of judges, 22 courts do not work in Ukraine]. Retrieved from: https://strana.ua/news/155866-vukraine-ne-rabotaet-dva-desjatka-sudov-iz-za-otsutstvija-sudej.html [in Russian]. 
17. Court of Appeal of Dnipropetrovsk region (2016a). Postanova Apeliatsiinoho sudu Dnipropetrovskoi oblasti vid 21 chervnia 2016 r. u spravi № 33/774/346/16 [Resolution of the Court of Appeal of Dnipropetrovsk region of June 21, 2016 in Case № 33/774/346/16]. Retrieved from: http://www.reyestr.court.gov.ua/Review/58480422 [in Ukrainian].

18. Court of Appeal of Cherkasy region (2016). Postanova Apeliatsiinoho sudu Cherkaskoi oblasti vid 13 chervnia 2016 r. u spravi № 710/649/16-ח [Decision of the Court of Appeal of Cherkasy region of June 13, 2016 in Case № 710/649/16-п]. Retrieved from: http://www.reyestr.court.gov.ua/Review/58279344 [in Ukrainian].

19. Court of Appeal of Kyiv region (2017). Postanova Apeliatsiinoho sudu Kyivskoi oblasti vid 18 zhovtnia 2017 r. u spravi № 374/161/17 [Resolution of the Court of Appeal of Kyiv region of October 18, 2017 in Case № 374/161/17]. Retrieved from: http://www.reyestr.court.gov.ua/ Review/69597068 [in Ukrainian].

20. Court of Appeal of Dnipropetrovsk region (2016b). Postanova Apeliatsiinoho sudu Dnipropetrovskoi oblasti vid 5 serpnia 2016 r. u spravi № 179/301/16-ח [Resolution of the Court of Appeal of Dnipropetrovsk region of August 5, 2016 in Case № 179/301/16-п]. Retrieved from: http://reyestr.court.gov.ua/Review/59527762 [in Ukrainian].

\title{
ЗАБЕЗПЕЧЕННЯ ПРАВ ЛЮДИНИ ПІД ЧАС ПРИТЯГНЕННЯ ДО АДМІНІСТРАТИВНОЇ ВІДПОВІДАЛЬНОСТІ ЗА ПРАВОПОРУШЕННЯ, ПОВ'ЯЗАНІ 3 КОРУПЦІЕЮ
}

\author{
Ірина Бойко, \\ доцент кафедри адміністративного права \\ Національного юридичного університету імені Ярослава Мудрого, \\ кандидат юридичних наук \\ orcid.org/0000-0003-3878-5985 \\ ir_boiko@ukr.net \\ Ольга Соловйова, \\ доцент кафедри адміністративного права \\ Національного юридичного університету імені Ярослава Мудрого, \\ кандидат юридичних наук, \\ orcid.org/0000-0003-3801-9113 \\ o.m.soloviova@gmail.com
}

Корупиія залишається однією з найбільших політичних і сочіально-економічних проблем України, щзо перешкоджає розбудові держави й громадянського суспільства, поглиблює суспільні кризові явища та загалом підриває імідж Украӥни на світовій арені. Розроблення й упровадження заходів антикорупиійного спрямування, особливо юридичної відповідальності, на практиці вимагає чіткого дотримання прочедури їх застосування з метою недопущення порушення прав осіб, яких вони стосуються. Ідеться про забезпечення балансу між невідворотністю покарання особи, яка вчинила правопорушення, пов'язане з корупџією, та ї̈ правами й свободами, щэо гарантовані чинним законодавством.

Мета статті полягає в дослідженні проблем правового регулювання провадження у справах про притягнення до відповідальності за порушення, пов'язані з корупцією, та формуванні пропозичій шодо їх вирішення. Досягнення сформульованої мети здійснюється за допомогою комплексного та послідовного застосування відповідного наукового інструментарію, представленого такими 
методами наукового пізнання, яклогіко-семантичний, системний, структурно-логічний, методи аналізу та синтезу тощзо.

Результати. У статті проаналізовано питання притягнення до адміністративної відповідальності за правопорушення, пов'язані з корупиією. Виявлено прогалини у правовому регулюванні відповідальності за правопорушення, пов'язані з корупиією, запропоновано шляхи вирімення окреслених проблем. Акиентовано увагу на необхідності дотримання гарантій справедливого суду в разі притягнення особи до адміністративної відповідальності за правопорушення, пов'язані з корупиією.

Висновки. Оскількинорми Кодексу Українипро адміністративні правопорушення не даютьзмогу повною мірою забезпечити особі право на справедливий суд, актуальною постає необхідність розроблення та прийняття закону про внесення змін до Кодексу України про адміністративні правопорушення або нової його редакиії, у якій було би враховано практику Європейського суду з прав людини у справах про правопорушення, пов'язані з корупцією.

Ключові слова: адміністративна відповідальність, правопорушення, пов'язані з корупцією, гарантії прав людини, право на справедливий суд. 